\title{
Production and evaluation of some extruded food products using spirulina algae
}

\author{
Morsy O.M.*; Sharoba A.M.; EL-Desouky A.I.; Bahlol H.E.M. and Abd EI Mawla E.M.** \\ Food Sci. Dept., Fac. of Agric., Moshtohor, Benha Univ., Egypt. \\ *Arab Academy for Science, Technology \& Maritime Transport, Arab League.
}

\begin{abstract}
In this study, spirulina which is one of the blue-green algae rich in protein $61.57 \%$ and contains a high proportion of essential amino acids (38.81\% of the protein) and a source of naturally rich in vitamins especially vitamin $B$ complex such as vitamin $B_{12}(193 \mu \mathrm{g} / 100 \mathrm{~g})$ and folic acid $(9.66 \mathrm{mg} / 100 \mathrm{~g})$, which helps the growth and nutrition of the child brain, also rich in calcium and iron it containing (1043.62 and $338.76 \mathrm{mg} / 100$ $\mathrm{g}$, respectively) to protect against osteoporosis and blood diseases as well as a high percentage of natural fibers. So, the spirulina is useful and necessary for the growth of infants and very suitable for children, especially in the growth phase, the elderly and the visually appetite. It also, helps a lot in cases of general weakness, anemia and chronic constipation. Spirulina contain an selenium element $(0.0488 \mathrm{mg} / 100 \mathrm{~g})$ and many of the phytopigments such as chlorophyll and phycocyanin $(1.472 \%$ and $14.18 \%)$, and those seen as a powerful antioxidant. It ensures the whole food and alkaline balance of the body. The spirulina used in the production of snack food by some addition percentages zero, 2.5, 5, 7.5, 10 and $12.5 \%$. Data of sensory evaluation results showed that the adding spirulina by ratio $12.5 \%$ had lower score for most properties compared to other tested. The chemical analysis was done, the obtained data showed that the add spirulina a large role in increasing protein ratio and ash where the results were $(9.43-18.11 \%)$ and $(1.31-2.67 \%)$ for the samples the control sample and $10 \%$ spirulina. The physical properties measurement were done, such as density, the expansion rate, grain index, WSI and WAI, the results showed that the adding rate of spirulina was improvmant the physical properties of the snacks. It was safety study microbiology samples prepared by adding snack spirulina and all samples were microbiologically safe. Rheological properties were measured for snacks samples by using (Instron universal testing machine model 4301) for measuring textures, all texture parameters were improved and increased constants textures add spirulina and was at the same time economical cost and therefore can be produced for domestic use as well as can be exported abroad.
\end{abstract}

Key words: Spirulina; nutritional value; chemical composition; amino acids, fatty acids, vitamins, phytopigments, minerals; microbiological examination; snacks.

\section{Practical Applications}

Extruded food products produced from cereals are usually low in protein and have a poor biological value due to their limited essential amino acid contents and are often fortified with proteins. Spirulina - cyanobacteria has been used by different populations as protein source and other nutritional requirement. Successful incorporation of spirulina into cereal-based extruded products could deliver physiologically active components, represents a major opportunity for food processors who are engaged in providing the consumer a healthy maizebased product, which is currently lacking in the market place.

\section{Introduction}

Spirulina is the dried biomass of the cyanobacterium Arthrospira platensis, it has been widely used in several countries, it is considered GRAS (generally recognized as safe), without toxicological effects, and it is approved by the FDA (U.S.A.) and ANVISA (Navacchi et al., 2012). Rich in protein (up to $65 \%$ ), spirulina is considered safe for consumption by molecules as phycocyanin, $\beta$ - carotene and xanthophyll pigments, $\alpha$-tocopherol and phenolic compounds, which are responsible for the antioxidant activities of these microalgae, as shown by several authors for in vitro and in vivo experiments (Patel et al., 2006). Moreover, most research has focused on the health effects of spirulina as a dietary supplement for humans and therapeutic applications: an anti-cancer effect (Mao et al., 2005), a hypolipidemic effect (Narmadha et al., 2012), and a protective effect against diabetes and obesity (Anitha and Chandralekh, 2010). These advantages make spirulina a good raw material for the healthy food.

Spirulina has no cellulose in its cell walls, being composed of soft mucopolysaccharides. This makes it easily digested and assimilated. It is 85 to $95 \%$ digestible. This easy digestibility is especially important for people suffering from intestinal malabsorption.

Spirulina can be used at any age (from infancy to pregnancy and adulthood), but its value is particularly evident in the young growing child: during weaning and during the pre-school period (from 1 to 6 years), Dillon (2014). 
Spirulina offers remarkable health benefits to an undernourished children. It is rich in beta-carotene that can overcome eye problems caused by vitamin A deficiency, it provides the daily dietary requirement of beta-carotene which can help prevent blindness and eye diseases Seshadri (1993). The protein and Bvitamin complex makes a major nutritional improvement in an infant's diet. It is the only food source other than breast milk containing substantial amounts of essential fatty acid, essential amino acids and GLA that helps to regulate the entire hormone system Ramesh et al. (2013).

Spirulina's concentrated nutrition makes it an ideal food supplement for people of all ages and lifestyles. Spirulina is about sixty percent complete, highly digestible protein. Spirulina contains every essential amino acids. It contains more beta-carotene than any other whole food; it is the best whole food source of gamma linolenic acid (GLA); it is rich in B vitamins, minerals, trace elements, chlorophyll, and enzymes; and it is abundant in other valuable nutrients about which scientists are learning more each year, such as carotenoids, sulfolipids, glycolipids, phycocyanin, superoxide dismutase, RNA and DNA (Robert (2010); Kelly et al. (2011) and Parry (2014)).

Spirulina platensis is used in the food, medicine, and cosmetic industries, and as an additive for chips, fruit juices, sauces, spice mixtures, vegetables, soups, and other products. This investigation contributes to the determination of nutrients in spirulina platensis microalgae used in the food and aquaculture feed industries.

Three to ten grams a day delivers impressive amounts of beta carotene, vitamin B-12 and B complex, iron, essential trace minerals, and gammalinolenic acid. Beyond vitamins and minerals, spirulina is rich in phytonutrients and functional nutrients that demonstrate a positive effect on health Robert (2010).

It is legally approved as a food or food supplement in Europe, Japan and many other countries around the globe. The United States Food and Drug Administration confirmed in 1981 that spirulina is a source of protein and contains various vitamins and minerals and may be legally marketed as a food supplement. Many countries have set up food quality and safety standards for spirulina, FDA (1981).

Extrusion cooking of cereals is a very important process in food industry, since it regards a wide range of products such as snack-foods, baby-foods, breakfast cereals, noodle, pasta and cereals based blends (Semaska et al., 2010). Extruders minimize the operating costs and higher productivity than other cooking process, combining energy efficiency and versatility. Corn meal is a major ingredient for extruded foods, such as ready-to-eat breakfast cereals and snacks (Jozinovic et al., 2012).
The market share of "ready-to-eat" food, "snack" food and breakfast cereals are growing almost everywhere in the world (Brncic $\boldsymbol{e t}$ al. 2006). Snack foods are prepared from natural ingredients or components to yield products with specified functional properties (Reid $\boldsymbol{e t}$ al. 1998). Snacks can be used as a vehicle for incorporating nutrients that have health benefits (Zazueta-Morales et al. 2002). Food extrusion has been widely used to produce ready to-eat cereals and snack foods. Physical characteristics of an extruded snack product such as expansion, hardness and density are important parameters in terms of the consumer acceptability as well as functional properties of the final product.

Extruded snack products are predominantly made from cereal flour because of their good expansion characteristics. However, extruded food products produced from cereals tend to be low in protein and have a poor biological value because of their limited essential amino acid contents (Iqbal et al. 2006). Many snack foods have low nutrient densities and are often fortified with proteins (Tangkanakul $\boldsymbol{e t}$ al., 1999).

As a carbohydrate source, maize is extensively used in the production of snack food by extrusion technology. Among the many available protein-rich food sources, spirulina is one of the magic foods that have immense nutritional importance. Spirulina cyanobacteria has been used as food for centuries by different populations. Concentrated nutrition of spirulina makes it an ideal food supplement for people of all ages and lifestyles. Only few published reports are available on the utilization of spirulina powder (SP) in food preparations like biscuits, cookies and chikki (Conrad 2004). However, the utilization of spirulina into maizebased extruded product has not been reported.

The effect of various extrusion parameters i.e., screw speed, barrel temperature, feed composition ratio and feed moisture content on the maizespirulina blend extruded product characteristics, and nutritional quality were studied by Joshi et al. (2014).

Extrusion has become a very important role in food processing operation. Today, the food extruder is used to produce pasta, ready-to eat cereals, snacks, confectionery products, modified starches for soup, baby food and instant foods, beverage bases and texturized vegetable proteins. Extrusion cooking technology is a high temperature-short time processing for the development of new innovative products. It minimizes energy, time and cost (Vijayarani et al., 2012).

Finally, spirulina called the ideal food for mankind and the World Health Organization considered its "super food" and the best food for the future because of its nutritional value is very high. The American space agency is working on a project to be grown in space and regards it as the main food for astronauts. All this and more is what makes the 
best food spirulina exists on the ground (Sharoba 2014).

Therefore, owing to all these advantages, the present work aims to study the physicochemical and nutritive values of spirulina, and formulate different extruded food products to use as a complementary for child and adult foods formulas with lower cost. To develop value added extruded products with different proportions of spirulina. Also, to assess the acceptable level of incorporation of spirulina powder in extruded products organoleptically, to evaluate the formulas from standpoint of organolyptically, physicochemical properties of the best formulas were evaluated, finally to analyse and compare the nutritional composition of the most acceptable developed extruded products.

\section{Materials and methods}

\section{Materials:}

Spirulina was obtained from Aquaculture Research Center at Arab Academy for Scince, Technology \& Maritime Transport, Arab League, Alexandria governorate, Egypt.

\section{Raw materials for experimental snack blends preparation:}

Some food ingredients were used as starting materials to produce spirulina snack (SS) products. These materials were obtained from the following sources:

A. Yellow corn grits (Zea mays L.), were obtained from "Egypt Food Company", Quisna, Minoufiya, Egypt.

\section{Chemical composition of corn grits}

\begin{tabular}{ll}
\hline Components & \multicolumn{1}{c}{$\%$} \\
\hline Moisture & $12.63 \pm 0.07$ \\
Protein* & $8.88 \pm 0.31$ \\
Fat* & $3.55 \pm 0.17$ \\
Ash* & $0.65 \pm 0.11$ \\
Crude fiber* & $2.24 \pm 0.06$ \\
Available carbohydrates** & 72.05 \\
\hline * (on dry weight basis) &
\end{tabular}

\section{** Available carbohydrate by difference:}

B. Chesse flavor was obtained from Quest International Egypt Company, 6 of October City, Giza, Egypt.

C. Palm olean oil was obtained from El-Motahda Company, Egypt.

D. Sodium chloride was purchased from the local markets.

\section{Technological treatments: Snack food preparation:}

The following procedures were carried out as preliminary steps, towards preparing the formulated food mixtures.
Production of experimental snack food preparation:

a) Formulation of experimental snack food blends:

Five blends were formulated, in addition to another one, the commercial product $(100 \%$ yellow corn grits) which served as control treatment. Total weight of each blend was about $20-25 \mathrm{~kg}$. The five experimental blends were prepared according to the percentages of constituent ingredients given in following table and each blend was named according to its distinguished constituent ingredient as follows:

Percentage of ingredients used to develop the snack products

\begin{tabular}{lcc}
\hline \multicolumn{1}{c}{ Blends } & $\begin{array}{c}\text { Corn flour } \\
(\%)\end{array}$ & $\begin{array}{c}\text { Spirulina } \\
(\%)\end{array}$ \\
\hline Blend (1) (0\% S) Control & $100 \%$ & - \\
Blend (2) $(2.5 \% \mathrm{~S})$ & $97.5 \%$ & $2.5 \%$ \\
Blend (3) $(5 \% \mathrm{~S})$ & $95.0 \%$ & $5.0 \%$ \\
Blend (4) $(7.5 \% \mathrm{~S})$ & $92.5 \%$ & $7.5 \%$ \\
Blend (5) $(10 \% \mathrm{~S})$ & $90.0 \%$ & $10.0 \%$ \\
Blend (6) $(12.5 \% \mathrm{~S})$ & $87.5 \%$ & $12.5 \%$ \\
\hline
\end{tabular}

\section{B) Extrusion apparatus:}

All equipments used to prepare the six experimental extruded products were existed at "Egypt Food Company" Quisna, Minoufiya, Egypt. Snack extrusion was made in single-screw extruder (type American extrusion) with production capacity of $150 \mathrm{~kg}$ per hour and four heating zones. Extrusion vibro feed hopper with vibrator and screw auger for easy metered flow of raw materials, quiet direct drive, and speed control of main drive via inverter. In general, yellow corn grits with moisture adjusted to $15 \%$ was used normally in such extrusion process.

The drier (Model 3000 Dryer American extrusion) passes hot dry air through the product which travels through the oven. This efficiently dries the product in 2 to 5 minutes using pelt conveyor equipped with diesel oil burner to raise temperature around $\left(115-125^{\circ} \mathrm{C}\right)$.

\section{C) Operation conditions for extrusion:}

Each blend was mix-fed to the extruder had modification for moisture content which ranged between (11.24 to $15.93 \%)$. The blends were mixed for $10 \mathrm{~min}$ before cook and extrusion. Blends were cooked by the single extruder American type at different extrusion operation conditions as follows: 1- Rotation screw speed $700 \mathrm{rpm}$ was used for all blends.

2- Two temperatures of extruder $\left(175\right.$ and $\left.180^{\circ} \mathrm{C}\right)$.

3 - The feeding rates ranged between 1.8 to $2 \mathrm{~kg} / \mathrm{min}$.

After the extrusion blends were dried at (115 and $125^{\circ} \mathrm{C}$ ) for 2 to $3 \mathrm{~min}$. A screw speeds (50 to 70 $\mathrm{rpm})$. By pelt conveyor oven equipped with diesel oil burner. 
D) Slurry preparation and application system:

American extrusion international melting tanks with double jacket water to raise temperature around $\left(40-45^{\circ} \mathrm{C}\right)$ are designed for oil slurry type seasoning application and will function with all standard coating application systems. The finished experimental extruded products were coated by chesse flavor blend which consisted of $6 \%$ chesse and $19 \%$ palm olean oil.

\begin{tabular}{|c|}
\hline \multicolumn{1}{|c|}{ Dried Spirulina powder } \\
\hline Yellow corn grits \\
$\downarrow$ \\
\hline Mixing (10 min) \\
$\downarrow$ \\
\hline Modification moisture \\
\hline$\downarrow$ \\
\hline Mixing (15 - 20 min) \\
\hline$\downarrow$ \\
\hline Extrusion \\
$\downarrow$ \\
\hline Drying \\
$\downarrow$ \\
\hline Coating 6\% chesse flavor + 19\% palm \\
Olean oil \\
$\downarrow$ \\
\hline Packing \\
\hline$\downarrow$ \\
\hline Analysis \\
\hline
\end{tabular}

Fig.1Flow chart for snacks processing

Methods:

Physicochemical analysis:

Moisture content, total solids, ash, fat, protein, ascorbic acid and starch were determined according to AOAC (2000). The $\mathrm{pH}$ value was measured with a $\mathrm{pH}$ meter model Consort $\mathrm{pH}$ meter P107. Titratable acidity was determined by titration with $\mathrm{NaOH} 0.1 \mathrm{~N}$ solution using phenolphthalein as indicator according to AOAC (2000). Total and reducing sugars were determined by Shaffer and Hartman method as described in the AOAC (2000). Total pectin content and fractional pectin components were determined by the method of Robertson (1979). Crude fiber was determined by Weende method in which VELP Scientifica extraction unit was used. The method is based on the solubilization of non-cellulosic compounds by sulfuric acid and hydroxide solutions as described in AOAC (2000). Total carotenoids were determined according to Harvey and Catherine (1982). Total anthocyanins was measured according to the method of Skalaki and Sistrunk (1973). Three replications of all these determinations were carried out. Carbohydrates were calculated by difference from the total of moisture dietary fibre, lipids, protein and ash contents (Sharoba et al., 2013). The total energy value of the food formulation was calculated according to Sharoba et al. (2013) using the formula as shown in the following equation:

Total energy $(\mathrm{kcal} / 100 \mathrm{~g})=[(\%$ available carbohydrates $\times 4)+(\%$ protein $\times 4)+(\%$ fat $\times 9)]$

\section{Amino acid analysis:}

The protein quantification was done with microKjeldahl method. Amino acid analysis procedure involves acid/alkaline hydrolysis, separation by cation exchange column, post-column derivatization with Ninhydrin and detection using UV/Vis detector at $570 \mathrm{~nm}$ as described in the Korean Food Code (KFDA, 2003). These procedures in the Korean Food Code were established based on AOAC Official Method $\mathbf{9 6 0 . 5 2}$ for micro-chemical determination of nitrogen (micro-Kjeldahl), AOAC Official Method 988.15 for tryptophan, AOAC Official Method 985.28 for sulfur amino acids, and AOAC Official Method 994.12 for acid-stable amino acids. After hydrolysis, amino acid analyzer (Sykam Gmbh, Germany) with an integrator (Axxiom Chromatography Inc.) was used for quantification of amino acids. All results are expressed on the basis of $100 \mathrm{~g}$ edible portion.

\section{Fatty acids composition analysis:}

The fatty acid profile was analyzed using a GasChromatographic model GC-17A according to AOAC (2000). Three samples of the oils which extracted from spirulina sample was converted to their corresponding methyl ester using boron trifluoride methanol complex $(14 \% \mathrm{w} / \mathrm{v})$. The mixture was maintained at $100{ }^{\circ} \mathrm{C}$ for $1 \mathrm{~h}$. The reaction was stopped with $0.5 \mathrm{ml}$ of distilled water. Then, the extracted fatty acid methyl esters (FAMEs) were dissolved in heptane for GC analyses. GC analyses were performed on a Hewlett-Packard 5890 Series II gas chromatograph (H.P. Co., Amsterdam, The Netherlands) equipped with a hydrogen flame ionization detector and a capillary column: HP Inovax cross-linked PEG (30 m x $0.32 \mathrm{~mm}$ x $0.25 \mathrm{~lm}$ film). The column temperature was programmed from 180 to $240{ }^{\circ} \mathrm{C}$ at $5^{\circ} \mathrm{C} / \mathrm{min}$ and the injector and detector temperature was set at $250{ }^{\circ} \mathrm{C}$. Nitrogen was the carrier gas. FAMEs were identified by comparison of their retention time with respect to pure standard FAMEs purchased from Sigma and analyzed under the same conditions. Date seed FAMEs were quantified according to their percentage area, obtained by integration of the peaks. The results were expressed as a percentage of individual fatty acids in the lipid fraction.

\section{Minerals content:}

Minerals content were determined according to AOAC (2000) using Perkin-elmer, 2380 Atomic absorption spectroscopy apparatus in central 
laboratory of Veterinary Faculty, Moshtohor according to AOAC (2000) official method 985.01. Meanwhile phosphorus was determined by the official spectrophotometric method of the AOAC (2000) using UV/visible automatic scanning spectrophotometer.

\section{Vitamins Assay:}

Vitamin C was determined in all samples by dichlorophenol Indophenol dye reduction method (AOAC, 2000).

Thiamine, Riboflavin, Niacin, Pyridoxine, Analogue, folic acid, inositol, vitamin E, vitamin K, Pantothenate and biotin were determined by the HPLC system method according to AOAC (2000). Determination of vitamin A: About $10 \mathrm{~g}$ of sample was homo-genized, weighed and transferred into a ground bottom flask, $30 \mathrm{ml}$ of extraction solution, $0.1 \%$ antioxidant and few drops of $\mathrm{KOH}$ were added and reflux for $30 \mathrm{~min}$ at $70^{\circ} \mathrm{C}$. The sample was cool down, vitamin A was extracted into hexane, and the combined hexane extract was washed with water and then dried the hexane layer to about $2 \mathrm{ml}$ on a rotary evaporator. The final volume was made up to $50 \mathrm{ml}$ with the mobile phase. The mobile phase, standard and sample were filtered through $0.45 \mu$ membrane filter and were degassed before injection. Calibration curve was made by a standard in mobile phase with five point calibrations and analyzed independently by HPLC. A standard curve was plotted between the concentration of vitamin A and peak area obtained. For HPLC analysis, an Eelipse $\times$ BD $-\mathrm{C} 18$ column $(4.6 \times 250 \mathrm{~mm} 5 \mu \mathrm{m})$ was used with a linear gradient of methanol: water (95:5) at constant flow rate of 1 $\mathrm{ml} / \mathrm{min}$ by using a binary pump with column tempera-ture $40^{\circ} \mathrm{C}$. A multiple wavelength detector was employed for the detection of pecks using a wavelength of $325 \mathrm{~nm}$ and a bandwidth of $8 \mathrm{~nm}$.

Phytopigments Assay:

Phytopigments content were determined according to AOAC (2000) by using HPLC.

All other chemicals were obtained from Merck (Darmstadt, Germany) or Riedel-de Haen (Seelze, Germany) as HPLC-grade. All standers materials were purchased from Merck (Darmstadt, Germany) or Sigma-Aldrich Chemicals Co. (Steinheim, Germany).

\section{Microbiological examination:}

Total viable bacterial count, mesophilic sporeformers bacteria, yeasts and moulds, coliform group were enumerated and the presence of (Salmonella spp. and Staphylococcus aureus) was detected according to the methods established by APHA (1992) and Kang et al. (2003). Results were

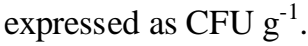

Rodent hairs and Insect fragments in spirulina:

Rodent hairs and insect fragments in spirulina were determined according Thind (2000).

Analytical methods for heavy metals in spirulina:
The determination of arsenic, cadmium and lead in spirulina sample were performed according to the methods described in the Korean Food Code (KFDA (Korea Food and Drug Administration, 2003) which described by Haeng-Shin et al. (2006) by inductively coupled plasma-emission spectrometry (Model JY 38 S; Horiba, Jobin Yvon Cedex, France). Duplicate samples were run in triplicates for the analysis of each heavy metal.

\section{Bulk density of spirulina:}

Bulk density (Kg/lit) was determined by gently pouring $2 \mathrm{~g}$ of spirulina into an empty $10 \mathrm{ml}$ graduated cylinder and holding the cylinder and tapping 10 times on a rubber mat from a height of 15 $\mathrm{cm}$. The ratio of the mass of the powder and the volume occupied in the cylinder was determines the bulk density according to Sharoba (2014).

\section{Determination of physical and functional properties \\ Bulk density of snachs (B.D) $\mathrm{g} / \mathrm{cm}^{3}$}

The bulk density of extrudates was determined according to the method described by Gujska and Khan (1991) where:

Bulk density $\left(\mathrm{g} / \mathrm{cm}^{3}\right)=$ Extruded weight/Extruded volume

However, samples obtained for measurement of extrudate expansion was also used to determine the bulk density.

\section{Grain index (g):}

Three random samples of 100 grains of snack food product were weighted and the average weight of these samples was reported as grain index by Myklestad et al. (1968).

\section{Expansion ratio (ER):}

Expansion ratio was measured according to the method described by Gujska and Khan (1990) which calculated as the diameter of the extrudate (D1) divided by the diameter of the die (d1).

$$
\text { Expansion ratio }=\frac{\text { Extrudate diameter of product (D1) }}{\text { Extrudate diameter of die (d1) }}
$$

\section{Water absorption:}

Water absorption was measured according to the procedure of Andersson et al. (1979) with some modifications. About $2 \mathrm{~g}$ sample was added to $1 \mathrm{ml}$ distilled water in a weighing centrifuge tube. Material was suspended in water by mixing with a thin glass rod without meal adhering to the side of the centrifuge tube. After a holding period of $30 \mathrm{~min}$, $10 \mathrm{ml}$ of distilled water were used to wash the meal adhering to the stirring rod and centrifuge tubes. The suspension was then centrifuged at $3000 \mathrm{rpm}$ for 25 min. The supernatant liquid was discarded and the tube was kept mouth down in forced draft air oven at $50^{\circ} \mathrm{C}$ for $20 \mathrm{~min}$, it was allowed to drain and dry, and then it was kept in desiccators at $\left(22 \pm 3^{\circ} \mathrm{C}\right)$ and subsequently weighted. Water absorption was 
expressed as the amount of water retained by $100 \mathrm{~g}$ of the sample.

Water absorption index (WAI) and water solubility index (WSI)

WAI (grams of gel recovered per gram of dry sample) and WSI (percent of dry sample in water layer) were determined according to the methods of Andersson and Hedlund (1991). Two grams of the sample were suspended in $30 \mathrm{ml}$ of water in a $50 \mathrm{ml}$ centrifuge tube at $30^{\circ} \mathrm{C}$., then stirred intermittently for $30 \mathrm{~min}$, and centrifuged at $3000 \mathrm{rpm}$ for 10 minutes. The supernatant liquid was carefully poured into a tared evaporating dish. The remaining gel was weighed and the WAI was determined. The amount of dried solids recovered by evaporating the supernatant from the water absorption test was expressed as percentage of dry solids. WSI and WAI were calculated according to the following equations:

$$
\begin{aligned}
\text { WSI } & =\frac{\text { Solids weight }}{\text { Weight of sample }} \times 100 \\
\text { WAI } & =\frac{\text { Weight of gel }}{\text { Weight of sample }} \times 100
\end{aligned}
$$

\section{Mechanical properties measurements:}

Texture parameters were measured on an Instron Universal Testing Machine (Model 4302) at Food Development Center, Kaha city, Kalyobia, Egypt using the Warner-Bratzler test $(5 \mathrm{~mm} \cdot \mathrm{min}-1 \mathrm{knife}$ speed; 0 to $500 \mathrm{~N}$ measuring cell) as described by Bourne (2002); Sharoba (2004) and Ravi et al., (2007). All tests were performed at room temperature $\left(25^{\circ} \mathrm{C}\right)$.

A force necessary to completely cut an extrudate sample with a single cut was recorded. The graphs obtained allowed to read sample hardness, $\mathrm{T}$ (the curve peak). The test device was interfaced to a computer and a printer, whereby a printout of the data obtained during each series of measurements $(6$ to 10 replicates) was produced.

\section{Mechanical measurements analysis:}

1-The force corresponding to the maximum compression is defined as the maximum force (Fmax). The maximum puncture force (Fmax) was measured in Newtons (N), as mentioned by Sharoba (2004).

2- The mean slope of the force-deformation curve was taken as stiffness and the actual area under the curve was expressed according to Sharoba (2004).

3- Maximum deformation: The distance from beginning to distance at maximum force.

4- Hardness = Maximum force (N)/Maximum deformation $(\mathrm{mm})$, as mentioned by Sharoba (2004).

Sensory evaluation of snacks:

Sensory evaluation was carried out on samples immediately after preparation. Sensory analysis was performed for selected experimental extruded products. A trained panel of staff of Food Science Department, Faculty of Agriculture Moshtohor, Benha University evaluated the extruded snacks for appearance (color and porosity), texture (hardness, crispness and brittleness) and overall acceptability and a modification number of evaluation the extruded snacks from nine point hedonic scale as follows: (very good $(90-80 \%)$, good $(60-70 \%)$, fair (40-50\%), poor (20-30\%) and very poor (0-10\%) ). The samples of approximately $5 \mathrm{~g}$ were presented in white cups labeled with random letters. The extrudates were offered to panelists at room temperature $\left(23^{\circ} \mathrm{C}\right)$. Panelists rinsed their mouths with water after tasting each sample. All sensory attributes were presented before sensory analysis. The sheet that contains definitions of sensory attributes was also placed in individual booths. Panelists evaluated hardness as the amount of force required to break the sample on first chew with molars. Crispness was measured as the degree to which breaking noise was heard. Brittleness was measured as capacity of a sample to break up into numerous pieces during the first bite. Porosity was visually evaluated as number of pores per unit area by panelists according to Altan et al. $(2008$ a, b) and Joshi et al. (2014).

\section{Statistical analysis:}

Data of chemical composition of ingredients and formulas were expressed as mean of three replicates \pm standard error (SE). Data for the sensory evaluation of all baby food formulas were subjected to the analysis of variance followed by multiple comparison using LSD (Snedecor and Cochran, 1989).

\section{Results and discussion}

\section{Chemical composition and nutritive values of spirulina:}

The Chemical composition and nutritional values of spirulina may vary according to the growing conditions. For example, the iodine content will vary as a function when the spirulina is grown in sea water vs. fresh water. The Chemical composition and nutritional values of dried powdered spirulina grown in fresh water is summarized in Tables (1, 2 and 3). It should be noted that, the cell wall of spirulina is composed of protein, carbohydrates and fat. Therefore, the bioavailability of nutrients from spirulina might be more than from other food sources, especially plant food sources.

Spirulina is the richest nutrient and complete food source found in the world. It contains over 100 nutrients, more than any other plants, grains or herbs. Today Spirulina is widely used as a food supplement to maintain health, boost energy and reduce weight. Spirulina contains $61.57 \%$ protein, higher than any other natural food. Spirulina contains all the essential amino acids in fairly high amounts, Spirulina is just 
that, a complete protein, other protein sources have very negative properties as well, such as animal fat and cholesterol. Spirulina contains essence minerals like calcium, magnesium, potassium, phosphorus, iron, and zinc as well as complete vitamin B groups and many important anti-oxidants (which protect cells). The anti-oxidant phycocyanin can only be found in spirulina. It is the richest natural source of vitamin $\mathrm{E}$ and beta-carotene. The results of chemical composition of spirulina are in agreement with those obtained by Branger et al. (2003); Habib et al. (2008); Vijayarani et al. (2012) and Dolly (2014). The protein and B-vitamin complex in spirulina makes a major nutritional improvement in the diet. It is the only food source other than breast milk containing substantial amounts of essential fatty acids, essential amino acids and GLA that helps to regulate the entire hormone system.

\section{Physical properties of spirulina:}

Spirulina offers a convenient solution to the $\mathrm{pH}$ problems of most diets as it is very alkaline. Because spirulina is an alkaline food $(\mathrm{pH}$ 6.93) that counters the acidic foods and help raise the $\mathrm{pH}$ level towards the alkaline side of the scale. This, in turn, promotes increased bone mass (since your body doesn't have to sacrifice calcium to balances its $\mathrm{pH}$ ), and vastly improved metabolic functions. Consuming more alkaline foods has been strongly linked with improved immune system function, mental function, kidney function, and higher levels of energy, among other important benefits. Acidic body condition may cause many modern diseases like hypertension, cancer, diabetes, heart disease, gout and rheumatism.

Adjust the body's pH value: The ideal healthy human body's $\mathrm{pH}$ level should remain on low alkaline about $\mathrm{pH} 7.35 \sim 7.45$. Modern day people indulge in too much acidic food like soft drinks, meat, cheese, eggs, and ham. These cause our body to become acidic $(\mathrm{pH}<7)$. Many medical research reports have proven that acidic bodies will have more chance of getting diseases or cancer. Regular use of Spirulina can help keep your body alkaline will help you reduce this risk and is the ideal food supplement for the weight reducer.

Table 1. Chemical composition and physical properties of Spirulina (g/100 g sample, on dry weight basis)

\begin{tabular}{lclc}
\hline \multicolumn{1}{c}{ Component } & Values \% & \multicolumn{1}{c}{ Physical properties } & Values \\
\hline Moisture content & $5.37 \pm 0.24$ & $\mathrm{pH}$ & $6.93 \pm 0.12$ \\
Total solids & 94.63 & Bulk density & $0.84 \pm 0.02 \mathrm{Kg} / \mathrm{lit}$ \\
Protein content & $61.57 \pm 1.61$ & Particle size & $100 \% 60 \mathrm{mesh}$ \\
Lipid & $7.19 \pm 0.25$ & Appearance & Fine, uniform powder \\
Ash content & $7.10 \pm 0.09$ & Color & Blue green to green \\
Crude fiber & $7.93 \pm 0.38$ & Odor and taste & Mild like sea weed \\
Starch & $3.47 \pm 0.06$ & Consistency & Powder \\
\hline
\end{tabular}

Data in Table (1) also showed the bulk density of spirulina $(0.84 \mathrm{Kg} / \mathrm{lit})$, the bulk density of the product is affected by particle size distribution, type of agglomeration, particle porosity, and to a certain extent the moisture content. Particle size distribution is affected by the initial size of the trichomes as they are fed to the dryer and the pore diameter of the atomizer. The final quality of the product with respect to bulk density is therefore dependent on culturing, harvesting and drying conditions. To a certain extent, all these factors are harnessed in order to obtain a product that meets the requirements of formulated babies food formulas. The color of spirulina in the powder form appears a blue green to green color.

Finally Spirulina called a superfood because its nutrient profile is more potent than any other food, such as plants, grains or herbs. These nutrients and phytonutrients make spirulina a whole food alternative to isolated vitamin supplements. Protein and amino acids, vitamins and minerals, essential fatty acids and phytonutrients, comparing with other foods. Spirulina can renourish our bodies and renew our health. Spirulina has been used in preparation sancks foods because of its therapeutic properties and the presence of antioxidant compounds. Babies can eat spirulina in complete safety and assimilate its nutrients without difficulty. Even malnourished babies with diminished capacity for nutrient absorption could assimilate spirulina and recover from malnutrition.

\section{Microbiological quality and contaminant specifications of Spirulina: Microbiological quality of Spirulina:}

The total viable bacterial count is widely used as an indicator microbiological quality of food. Data in Table (4) indicated that, the total viable bacterial count and mesophilic spore formers bacteria were cannot be detected. This is more acceptable for prepared food product especially snacks and baby foods. Yeasts and moulds cannot be detected, this may that yeast and moulds cannot resist for drying. The count of pathogenic bacteria took the same trend of total viable bacterial count. Coliform group, salmonella and staphylococcus were not detected. 
Table 2. Amino acids and fatty acids content of Spirulina (mg/100 g).

\begin{tabular}{|c|c|c|c|}
\hline Amino acids & Values & Fatty acids & Values \\
\hline Essential amino acids & $\%$ & Myristic (C14:0) & 0.52 \\
\hline Isoleucine & 6.78 & Palmitic (C16:0) & 39.87 \\
\hline Leucine & 7.67 & Palmitoleic (C16:1 omega-6) & 6.46 \\
\hline Lysine & 4.37 & Stearic $(\mathrm{C} 18: 0)$ & 1.97 \\
\hline Methionine & 2.39 & Oleic (C18:1 omega-6) & 1.83 \\
\hline Phenylalanine & 4.42 & Linoleic (C18:2 omega-6) & 17.91 \\
\hline Threonine & 4.88 & Gamma-linolenic (C18:3 omega-6) & 24.58 \\
\hline Tryptophan & 1.93 & Alpha-linolenic (C18:3 omega-3) & traces \\
\hline Valine & 6.37 & Erucic acid $(\mathrm{C} 22: 1)$ & 5.39 \\
\hline Total & 38.81 & Lignoceric acid (C24:0) & 1.47 \\
\hline Non-essential amino acids & $\%$ & Total saturate fatty acid & 43.83 \\
\hline Alanine & 7.52 & Total unsaturated fatty acid & 56.17 \\
\hline Arginine & 7.65 & & \\
\hline Aspartic & 11.17 & & \\
\hline Cysteine & 1.28 & & \\
\hline Glutamic & 13.79 & & \\
\hline Glycine & 5.24 & & \\
\hline Histidine & 2.71 & & \\
\hline Proline & 4.35 & & \\
\hline Serine & 4.16 & & \\
\hline Tyrosin & 3.48 & & \\
\hline Total & 61.19 & & \\
\hline Total amino acids & $100 \%$ & & \\
\hline$\%$ Protein & 61.57 & & \\
\hline
\end{tabular}

Table 3. Vitamins, phytopigments and minerals in Spirulina.

\begin{tabular}{|c|c|c|c|}
\hline Components & Values & Components & Values \\
\hline 1. Vitamins & (Values /100g) & 3. Minerals & $(\mathrm{mg} / 100 \mathrm{~g})$ \\
\hline Vitamin B1(Thiamine) & $5.61 \mathrm{mg}$ & Ca Calcium & 1043.625 \\
\hline Vitamin B2 (Riboflavin) & $4.94 \mathrm{mg}$ & K Potassium & 2185.744 \\
\hline Vitamin B3 (Niacin) & $17.19 \mathrm{mg}$ & Mg Magnesium & 1.4759 \\
\hline Vitamin B6 (Pyridoxine) & $0.87 \mathrm{mg}$ & Na Sodium & 1510.168 \\
\hline Vitamin $B_{12}$ (Analogue) & $193 \mu \mathrm{g}$ & P Phosphprus & 1917.718 \\
\hline Folic acid & $9.66 \mathrm{mg}$ & $\mathrm{Cu}$ Copper & 1.5071 \\
\hline Inositol & $58.39 \mathrm{mg}$ & Fe Iron & 338.765 \\
\hline Vitamin E & $9.57 \mathrm{mg}$ & Mn Manganese & 7.0194 \\
\hline Vitamin K & $1124 \mu \mathrm{g}$ & Zn Zinc & 4.4924 \\
\hline Pantothenate & $136 \mu \mathrm{g}$ & Cr Chromium & 0.403 \\
\hline Biotin & $8.32 \mu \mathrm{g}$ & Se Selenium & 0.0488 \\
\hline 2. Phytopigments & $(\%)$ & B Boron & 3.565 \\
\hline Total Carotenoids & 0.551 & Mo Molybdenum & 0.4613 \\
\hline beta carotenoids & 0.243 & & \\
\hline Xanthophylls & 0.271 & & \\
\hline Zeaxanthin & 0.128 & & \\
\hline Chlorophyll & 1.472 & & \\
\hline Phycocyanin & 14.18 & & \\
\hline
\end{tabular}


Table 4. Microbiological quality of Spirulina (CFU/g)

\begin{tabular}{lc}
\hline Test & Values \\
TVBC (Total viable bacterial count) & negative \\
\hline MSB (Mesophilic Spore formers bacteria) & ND \\
Y\&M (Yeasts and Moulds) & ND \\
Coliform group & ND \\
Salmonella & ND \\
Staphylococcus & ND \\
\hline
\end{tabular}

\section{Contaminant specifications of Spirulina:}

Data in Table (5) indicated that, the spirulina free from pesticides, rodent hairs and insect fragments. On the other hand, the level of heavy metals in line with the specifications of the global food, these results are in agreement with those obtained by Haeng-Shin et al. (2006) and Llobet et al. (2003) Used spirulina in production of snack foods:

In view of importance of snack foods in the dietary habits of Egyptian children and the increased consumption by different other classes of the Egyptian community, the present study was initiated to investigate the possibility of producing some improved snack products based mainly on some spirulina.

Using the sensory evaluation to select the best ratio in addition of spirulina in snacks:

Sensory evaluation is considered one of the limiting factors of consumer acceptability for organoleptic properties including appearance (color and porosity), taste (bran flavor, bitterness, off-odor and after taste), texture (hardness, crispness, brittleness and Firmness), odor (odor raw material, stink odor, undesirable odor and old odor), solubility in mouth, volume and over all acceptability. Data indicated that a significant $(\mathrm{P}<0.05)$ changes were found in all properties for all experimental products.
Data in Table (6) showed that sample 6 (12.5\% spirulina, blend (6)) had lower scores for most properties compared to the other tested products. Besides it showed the lowest score for overall acceptability (59.88). The highest over all acceptability scores were registered for sample content $2.5 \%$ spirulina, blend (2). The highest score for appearance, also the highest score for color and the highest score for porosity, also, the highest scores for taste, bitterness, off-odor, texture, volume, hardness, crispness, brittleness and after taste

These obtained results for organoleptic properties are in agreement with those of Hussein (2000); El-Sharkawi (2004); Kabiel (2007); Vijayarani et al. (2012); Nour El-Deen (2013) and Joshi et al . (2014).

Finally, the results showed that in all the sensory qualities that increase the proportion of spirulina about $10 \%$ less than in the sensory qualities, especially color and appearance. Also these results were confirmed by the results of the physical properties of snacks. Therefor we had been stopped at using $10 \%$ spirulina in snacks processing. Also, the results for organoleptic properties are in agreement with those of Maity et al. (2012); Alam et al. (2013) and Raja et al. (2014) they found that, the addition of sources of protein and fiber improved the sensory properties of snacks.

Table 5. Contaminant specifications of spirulina

\begin{tabular}{lc}
\hline Test & Values \\
\hline Arsenic & $<1.0 \mathrm{ppm}$ \\
Cadmium & $<0.5 \mathrm{ppm}$ \\
Lead & $<0.5 \mathrm{ppm}$ \\
Mercury & $<0.05 \mathrm{ppm}$ \\
Pesticides & negative \\
Rodent hairs & $\mathrm{ND}$ \\
Insect fragments & $\mathrm{ND}$ \\
\hline
\end{tabular}


Table 6. Sensory evaluation for experimental snacks foods blends prepared from the different blends investigated.

\begin{tabular}{|c|c|c|c|c|c|c|c|c|}
\hline & & & Gro & aps of experi1 & ental extrudec & foods* & & \\
\hline & Property & $\begin{array}{c}\text { Blend } 1 \\
0 \% \\
\text { spirulina } \\
\end{array}$ & $\begin{array}{c}\text { Blend } 2 \\
2.5 \% \\
\text { spirulina } \\
\end{array}$ & $\begin{array}{c}\text { Blend } 3 \\
5 \% \\
\text { spirulina } \\
\end{array}$ & $\begin{array}{c}\text { Blend } 4 \\
7.5 \% \\
\text { spirulina } \\
\end{array}$ & $\begin{array}{c}\text { Blend } 5 \\
10 \% \\
\text { spirulina } \\
\end{array}$ & $\begin{array}{c}\text { Blend 6 } \\
12.5 \% \\
\text { spirulina } \\
\end{array}$ & $\begin{array}{c}\text { LS } \\
\mathrm{D}\end{array}$ \\
\hline ฮี & $\underset{\circlearrowright}{8}$ Color & $9.53 \pm 0.28$ & $9.48 \pm 0.61$ & $8.52 \pm 0.47$ & $8.11 \pm 0.52$ & $7.89 \pm 0.32$ & $5.93 \pm 0.28$ & 0.54 \\
\hline 㝴 & ${ }^{*}$ Porosity & $9.23 \pm 0.51$ & $9.36 \pm 0.57$ & $8.32 \pm 0.61$ & $8.19 \pm 0.37$ & $7.01 \pm 0.30$ & $5.55 \pm 0.47$ & 0.59 \\
\hline & Bran flavor & $4.88 \pm 0.14$ & $4.74 \pm 0.25$ & $4.69 \pm 0.24$ & $4.86 \pm 0.32$ & $3.91 \pm 0.17$ & $3.21 \pm 0.14$ & 0.18 \\
\hline$\tilde{g}$ & Bitterness & $4.56 \pm 0.23$ & $4.91 \pm 0.17$ & $4.65 \pm 0.28$ & $4.45 \pm 0.27$ & $3.96 \pm 0.31$ & $3.88 \pm 0.27$ & 0.23 \\
\hline$\stackrel{q}{\tilde{E}}$ & Off-odor & $4.60 \pm 0.19$ & $4.85 \pm 0.33$ & $4.65 \pm 0.28$ & $4.42 \pm 0.11$ & $4.01 \pm 0.17$ & $3.68 \pm 0.30$ & 0.31 \\
\hline & After taste & $4.66 \pm 0.24$ & $4.96 \pm 0.17$ & $4.82 \pm 0.31$ & $4.72 \pm 0.27$ & $3.53 \pm 0.14$ & $3.28 \pm 0.25$ & 0.26 \\
\hline & Hardness & $3.96 \pm 0.17$ & $4.76 \pm 0.21$ & $4.91 \pm 0.12$ & $4.96 \pm 0.24$ & $3.89 \pm 0.09$ & $2.92 \pm 0.15$ & 0.17 \\
\hline$\stackrel{\mathscr{U}}{=}$ & Crispness & $4.91 \pm 0.28$ & $4.75 \pm 0.19$ & $4.63 \pm 0.18$ & $4.23 \pm 0.14$ & $3.76 \pm 0.20$ & $3.49 \pm 0.31$ & 0.24 \\
\hline 氛 & Brittleness & $4.86 \pm 0.25$ & $4.96 \pm 0.18$ & $4.76 \pm 0.26$ & $4.12 \pm 0.17$ & $3.75 \pm 0.12$ & $3.28 \pm 0.24$ & 0.18 \\
\hline & Firmness & $4.74 \pm 0.26$ & $4.86 \pm 0.18$ & $4.92 \pm 0.27$ & $4.56 \pm 0.13$ & $4.44 \pm 0.15$ & $2.68 \pm 0.19$ & 0.29 \\
\hline & $\begin{array}{l}\text { Odor raw } \\
\text { material }\end{array}$ & $3.88 \pm 0.09$ & $4.79 \pm 0.14$ & $4.83 \pm 0.23$ & $4.89 \pm 0.16$ & $3.96 \pm 0.24$ & $3.98 \pm 0.17$ & 0.27 \\
\hline ö & Stink odor & $4.92 \pm 0.13$ & $4.68 \pm 0.28$ & $4.36 \pm 0.17$ & $4.21 \pm 0.09$ & $3.12 \pm 0.31$ & $2.92 \pm 0.10$ & 0.16 \\
\hline 8 & $\begin{array}{l}\text { Undesirabl } \\
\text { e Odor }\end{array}$ & $4.96 \pm 0.20$ & $4.82 \pm 0.27$ & $4.32 \pm 0.14$ & $4.16 \pm 0.26$ & $3.51 \pm 0.18$ & $2.67 \pm 0.18$ & 0.19 \\
\hline & Old odor & $4.72 \pm 0.08$ & $4.66 \pm 0.12$ & $4.56 \pm 0.18$ & $4.32 \pm 0.18$ & $3.78 \pm 0.27$ & $2.58 \pm 0.21$ & 0.23 \\
\hline & $\begin{array}{l}\text { Solubility in } \\
\text { mouth }\end{array}$ & $9.69 \pm 0.28$ & $9.36 \pm 0.53$ & $8.89 \pm 0.43$ & $8.37 \pm 0.36$ & $7.01 \pm 0.40$ & $5.86 \pm 0.63$ & 0.42 \\
\hline & Volume & $9.86 \pm 0.24$ & $9.48 \pm 0.36$ & $9.31 \pm 0.42$ & $8.76 \pm 0.51$ & $7.16 \pm 0.39$ & $5.84 \pm 0.84$ & 0.53 \\
\hline & $\begin{array}{l}\text { Over all } \\
\text { cceptability }\end{array}$ & $87.19 \pm 1.27$ & $89.79 \pm 2.38$ & $87.89 \pm 1.68$ & $84.39 \pm 1.79$ & $71.66 \pm 1.46$ & $59.88 \pm 2.24$ & 2.14 \\
\hline
\end{tabular}

\section{Chemical composition of snacks blends:}

Chemical composition of snack foods are given in Table (7). There were significant $(\mathrm{P}>0.05)$ differences in crude fat, ash, crude protein and carbohydrates contents among all experimental products, but not in moisture content. Data in Table (7) demonstrated that moisture content was low in all products (ranged from 4.83 to $7.15 \%$ ), while ether extracts content was higher in all products (ranged from 18.65 to 20.38). These results are in agreement with those found by El-Sharkawi (2004), Kabiel (2007), Vijayarani et al. (2012), Nour El-Deen (2013) and Joshi et al.(2014). The highest amount of ash (2.67) was in snacks sample content $10 \%$ spirulina followed by snacks sample content $7.5 \%$ spirulina and the lowest ash content was in control sample. On the other hand, It became clear to add significant impact on spirulina protein in sancks samples, the highest level of crude protein content $(18.11 \%)$ was found in snacks sample content $10 \%$ spirulina followed by snacks sample content $7.5 \%$ spirulina (15.94\%). Besides, there were significant differences in protein content between extrudate experimental product. The highest amount of carbohydrates $(63.33 \%)$ was in commercial sample product followed by control sample $(62.91 \%)$, while the lowest carbohydrates content was in snacks sample product content $10 \%$ spirulina (54.98\%), these results are in agreement with those found by El-Sharkawi (2004), Kabiel (2007), Vijayarani et al. (2012), Nour El-Deen (2013) and Joshi et al.(2014). 
Table 7. Chemical composition of snacks foods blends (Mean \pm SE):

\begin{tabular}{lcccccc}
\hline \multirow{2}{*}{ Components } & \multicolumn{5}{c}{ Snacks foods blends } & Commercial \\
& Blend 1 & Blend 2 & Blend 3 & Blend 4 & Blend 5 & Comple \\
& $0 \%$ & $2.5 \%$ & $5 \%$ & $7.5 \%$ & $10 \%$ & \\
\hline Spirulina & spirulina & spirulina & spirulina & spirulina & \\
\hline Moisture (\%) & $6.27 \pm 0.17$ & $5.88 \pm 0.08$ & $5.53 \pm 0.13$ & $5.04 \pm 0.17$ & $4.83 \pm 0.07$ & $7.15 \pm 0.038$ \\
Crude protein (\%) & $9.43 \pm 0.11$ & $11.38 \pm 0.09$ & $13.72 \pm 0.13$ & $15.94 \pm 0.17$ & $18.11 \pm 0.12$ & $9.28 \pm 0.22$ \\
Ether extract (\%) & $20.38 \pm 0.85$ & $19.86 \pm 0.69$ & $19.79 \pm 0.81$ & $19.63 \pm 0.56$ & $19.41 \pm 0.43$ & $18.65 \pm 0.69$ \\
Ash (\%) & $1.31 \pm 0.02$ & $1.76 \pm 0.01$ & $1.96 \pm 0.04$ & $2.28 \pm 0.02$ & $2.67 \pm 0.01$ & $1.59 \pm 0.01$ \\
Carbohydrate (\%) & 62.91 & 61.12 & 59.00 & 57.11 & 54.98 & 63.33 \\
Caloric value & 472.78 & 468.74 & 468.99 & 468.87 & 467.05 & 458.29 \\
(kcal/100g) & & & & & & \\
\hline
\end{tabular}

Physical and functional properties of experimental snacks foods prepared from the different ratio of spirulina:

Physical and functional properties of extruded preparations are given in Table (8). There were significant $(\mathrm{P}>0.05)$ differences in all Physical and functional properties with adding spirulina. Values for bulk density (BD), grain index, expansion rate, water solubility index (WSI) and water absorption index (WAI) are represented in Table (8).

Bulk density (BD) is a major physical property of the extrudate products. The $\mathrm{BD}$, which considers expansion in all direction, ranged from 0.18 to $0.32 \mathrm{~g} / \mathrm{cm}^{3}$. Increasing level of temperature resulted decrease in BD of extrudate. High temperature results in more starch gelatinization. Case et al. (1992) and Joshi et al.(2014) reported that with increase in starch gelatinization, the volume of the extrudate increases and the BD decreases. It appeared that with the increase in screw speed, BD increased because of less expansion.

Such increase could be due to the high protein and fiber contents as a result to the presence the spirulina in the starting blends. Õzer et al. (2004) and Kabiel (2007) have reported the existence of a relationship between the screw speed (rpm) and the bulk density of the extrudates. Also, it could be observed that increasing percentage of defatted soybean from 15 to $25 \%$ had resulted in a significant increase in the bulk density of the extrudates. This could be ascribed to the increase screw speed that decreased the time which in turn definitely affect the gelatinization process of starch. These results are in agreement with those reported by Murphy $\boldsymbol{e t} \boldsymbol{a l}$. (2003), Ainsworth et al. (2007) and Altan et al. (2008a).

Data in Table (8) cleared that the grain index values ranged between 6.78 to $7.59 \mathrm{~g}$ where the lower limit was in product control sample $(0 \%$ spirulina) and the higher limit was in product sample content $10 \%$ spirulina Various investigators have reported the milling process led to a decline in grain index. The obtained data are related to the bulk density where the rate of changes depends on the ratio of spirulina.

Expansion rate could be improved by increasing screw speed. In the present study the raw material, moisture content, extrudate expansion and fracture stress are correlated. High moisture content during extrusion reduced expansion of the extrudate and increased the fracture stress as reported previously by Suknark et al. (1999) and Wang et al. (1999). The extrudates product control sample $(0 \%$ spirulina) and the higher limit was in product sample content $10 \%$ spirulina. These results are in agreement with those reported by Obatolu et al. (2005) and Carvalho et al. (2010).

WSI used as an indicator of degradation of molecular components. It measures the amount of soluble polysaccharide released from the starch component after extrusion (Ding et al. 2005). The WSI ranged from 8.21 to $10.09 \%$; however, WSI decreased with increasing the levels of feed moisture content. It may be due to higher moisture content of the blend resulted in the lower viscosity of the mass liquefied in the extrusion-cooker and thus the intensity impact of the shearing forces on the material processed was lower and it also decreased the degree of dextrinization of the starch polymers. This results are in agreement with Ragab (1992) and Kabiel (2007).

WAI measures the amount of water absorbed by starch that can be used as an index of gelatinization. The WAI ranged from 4.89 to 6.37 $\mathrm{g} / \mathrm{g}$. WAI increased at higher levels of moisture content of blend. Moisture acts as a plasticizer during extrusion cooking and reduces the degradation of starch granule, resulting in increased capacity for water absorption according the (Hagenimana $\boldsymbol{e t}$ al. (2006) and Joshi et al.(2014)).

In general, water absorption index (WAI) depends on availability of hydrophilic groups which bind water molecules and on the gel forming capacity of macromolecules for gelatinized corn flours. These findings suggested that smaller starch particles have a greater contact area for shear fragmentation during extrusion which leads to increased dextrinization and improves its water absorption capacity. The WAI estimates the amount of water absorbed by starch and can be used as an index of gelatinization, since it is known that disrupted starch granule binds more water (Ding $\boldsymbol{e t}$ $a l ., 2005 \& 2006$ and Semaska et al.2010). 
Table 8. Physical and functional properties of experimental extruded products prepared from the different ratio of spirulina

\begin{tabular}{|c|c|c|c|c|c|c|}
\hline \multirow[b]{2}{*}{ Property } & \multicolumn{5}{|c|}{ Groups of experimental extruded products* } & \multirow[b]{2}{*}{ L.S.D. } \\
\hline & $\begin{array}{c}\text { blend } 1 \\
\text { (0\% spirulina) }\end{array}$ & $\begin{array}{c}\text { blend } 2 \\
(2.5 \% \\
\text { spirulina) }\end{array}$ & $\begin{array}{c}\text { blend } 3 \\
\text { (5\% spirulina) }\end{array}$ & $\begin{array}{c}\text { blend } 4 \\
\text { ( } 7.5 \% \text { spirulina })\end{array}$ & $\begin{array}{c}\text { blend } 5 \\
\text { (10\% spirulina) }\end{array}$ & \\
\hline Bulk density & $0.18 \pm 0.00$ & $0.21 \pm 0.01$ & $0.25 \pm 0.02$ & $0.28 \pm 0.01$ & $0.32 \pm 0.01$ & 0.03 \\
\hline Grain index & $6.78 \pm 0.21$ & $6.93 \pm 0.17$ & $7.14 \pm 0.11$ & $7.33 \pm 0.28$ & $7.59 \pm 0.15$ & 0.19 \\
\hline Expansion rate & $4.89 \pm 0.17$ & $4.67 \pm 0.09$ & $4.31 \pm 0.10$ & $4.07 \pm 0.12$ & $3.86 \pm 0.08$ & 0.21 \\
\hline WSI\%* & $8.21 \pm 0.15$ & $8.69 \pm 0.37$ & $8.94 \pm 0.23$ & $9.45 \pm 0.33$ & $10.09 \pm 0.29$ & 0.28 \\
\hline WAI $\% *$ & $4.89 \pm 0.08$ & $5.24 \pm 0.26$ & $5.73 \pm 0.13$ & $6.02 \pm 0.14$ & $6.37 \pm 0.11$ & 0.16 \\
\hline
\end{tabular}

** Values represent mean of three replicates \pm standard error.

$* * *$ Means with different superscripts are significantly different $(\mathrm{P}>0.05)$.

$\mathrm{WSI}=$ water solubility index. $\quad \mathrm{WAI}=$ water absorption index

\section{Microbiological quality of experimental extruded snack food products prepared from the different ratio of spirulina:}

Microbiological quality of extruded preparations are given in Table (9). Experimental extruded products were examined for total bacterial count, yeasts and molds counts and coliform groups directly after processing and packaging and the obtained results were illustrated in Table (9). Total bacterial counts (TBC), yeasts and molds counts were absent from all tested samples. On the other hand, coliform group was not recovered also from all tested samples. The spirulina adding it had higher antimicrobial effects Ramadan $\boldsymbol{e t}$ al. (2008) and the heat treatments for all products were being responsible for such absence Kabiel (2007) and Nour El-Deen (2013).
They could not be detected or recovered because the starting mixtures during processing were treated with heat at high temperature $\left(180^{\circ} \mathrm{C}\right)$. The effect of such heat treatment may be same as commercial sterilization of food. This result is in general agreement with those Kabiel (2007); Maity et al. (2012); Vijayarani et al. (2012) and Raja et al. (2014). However, yeast and mold counts in the present study were distinctly much lower, even absent completely, compared to that of total bacterial count reported by Kabiel (2007); Maity et al. (2012); Vijayarani et al. (2012) and Raja et al. (2014). The same author added "although it is well known that most vegetative organisms, yeast and moulds are destroyed under typical extrusion conditions, the operating conditions under which spores are inactivated are not well understood".

Table 9. Microbiological quality of experimental extruded snacks foods prepared from the different ratio of spirulina and commercial snack sample (CFU/g).

\begin{tabular}{lccc}
\hline Snack blends & TVBC & Y\&M** & Coliform group \\
\hline Commercial snacks & $3.0 * 10^{2}$ & $4 * 10$ & ND \\
blend (1) $0 \%$ spirulina & ND & ND & ND \\
blend (2) $2.5 \%$ spirulina & ND & ND & ND \\
blend (3) $5 \%$ spirulina & ND & ND & ND \\
blend (4) $7.5 \%$ spirulina & ND & ND & ND \\
blend (5) $10 \%$ spirulina & ND & ND &
\end{tabular}

$*(\mathrm{TVBC})=$ Total viable bacterial count $* * \mathrm{Y} \& \mathrm{M}=$ Yeasts and Moulds $\quad * * * \mathrm{ND}=$ Not detected

Texture parameters of experimental extruded snacks foods products prepared from the different ratio of spirulina:

Texture parameters of extruded preparations are given in Table (10). There were significant $(\mathrm{P}>0.05)$ differences in texture properties and ratio of adding of spirulina. Data in Table (10) illustrate the various texture parameters, mainly, maximum force $(\mathrm{N})$, maximum deformation $(\mathrm{mm})$, hardness $(\mathrm{N} / \mathrm{mm})$ and work (J). These texture parameters of the extruded snacks were determined as the maximum force offered by the sample during shearing in a texture-testing machine (Instron). Results data in Table (10) demonstrated that the maximum force for all samples of different snack products ranged between 47.23 and $126.31 \mathrm{~N}$ in extrudate products for the extrudates product control sample $(0 \%$ spirulina) and the sample content $10 \%$ spirulina, the replacement corn flour with spirulina improved the texture parameters in all extrudate produced. On the other hand, the higher of maximum force and hardness for snacks which content with spirulina related to low moisture and increase hardness, on other side increased work done. Hardness of different extrudate samples varied between 8.587 to 22.965 $\mathrm{N} / \mathrm{mm}$ in extrudate products for the extrudates product control sample (0\% spirulina) and the sample content $10 \%$ spirulina. The hardness of expanded extrudate is a perceptible to consumers, and may be correlated with the expansion and cell structure of 
the product, independent of the feed moisture content, these results are in agreement with Ding $\boldsymbol{e t}$ al. (2005); Ravi et al., (2007); Maity et al. (2012); Alam et al. (2013) and Raja et al. (2014). These data as an indicator of hardness were measured by shearing through the $1 \mathrm{~cm}$ height to 50 to $60 \%$ of their original height at a speed of $5 \mathrm{~mm} / \mathrm{min}$. Maximum force and hardness for different sample of snack products, indicating that the different blends improvement the texture parameters.

Table 10. Texture parameters of snacks foods (Mean \pm SE):

\begin{tabular}{|c|c|c|c|c|c|c|}
\hline \multirow[b]{2}{*}{ Texture parameters } & \multicolumn{5}{|c|}{ Snacks foods } & \multirow[b]{2}{*}{$\begin{array}{l}\text { Commercial } \\
\text { snacks }\end{array}$} \\
\hline & $\begin{array}{c}\text { blend (1) } \\
0 \% \\
\text { spirulina }\end{array}$ & $\begin{array}{c}\text { blend (2) } \\
2.5 \% \\
\text { spirulina }\end{array}$ & $\begin{array}{c}\text { blend (3) } \\
5 \% \\
\text { spirulina }\end{array}$ & $\begin{array}{c}\text { blend (4) } \\
7.5 \% \\
\text { spirulina }\end{array}$ & $\begin{array}{c}\text { blend (5) } \\
10 \% \\
\text { spirulina }\end{array}$ & \\
\hline Maximum Force(N) & $47.23 \pm 1.38$ & $64.27 \pm 1.07$ & $82.38 \pm 1.13$ & $102.19 \pm 1.63$ & $126.31 \pm 1.85$ & $53.83 \pm 1.92$ \\
\hline $\begin{array}{l}\text { Maximum } \\
\text { deformation(mm) }\end{array}$ & 5.5 & 5.5 & 5.5 & 5.5 & 5.5 & 5.5 \\
\hline Hardness (N/mm) & 8.587 & 11.685 & 14.978 & 18.580 & 22.965 & 9.787 \\
\hline Work (J) & 87.00 & 109.64 & 126.68 & 146.92 & 160.54 & 92.13 \\
\hline
\end{tabular}

Each value is the average of three replicates

The textural property of extrudate snack was determined by measuring the force required to break the extrudate. The higher value of maximum peak force required in gram, which means the more force required to breakdown the sample, the higher hardness of the sample to fracture.

\section{Conclusions}

A spirulina farm is an environmentally sound green food machine. Cultivated in shallow ponds, this algae can double its biomass every 2 to 5 days. This productivity breakthrough yields over 20 times more protein than soybeans on the same area, 40 times corn and 400 times beef. Spirulina can flourish in ponds of brackish or alkaline water built on already unfertile land. In this way, it can augment the food supply not by increase the agricultural area or increasing agricultural intensification in Egypt, or clearing the disappearing rainforests in the world, but by cultivating the expanding deserts. Finally from this research we can use as spirulina recommended by the United Nations World Health Organization (WHO) which confirmed that spirulina represents an interesting food for multiple reasons, rich in iron and protein, it can be safely administered to babies without any risk.

\section{References}

Ainsworth P.; Ibanoglu S.; Plunkett A.; Ibanoglu E. and Stojceska V. (2007) Effect of brewers spent grain addition" and screw speed on the selected physical and nutritional properties of an extruded snack. J. Food Eng., 81(4): 702-709.

Alam MD. S.; Singh B.; Khaira H.; Kaur J. and Singh S.K. (2013) Optimization of extrusion process variables for development of pulse-carrot pomace incorporated rice based snacks. Journal of Food Legumes 25(1) 1-18.

Altan A.; McCarthy K.L. and Maskan M. (2008a) Evaluation of snack foods from barley- tomato pomace blends by extrusion processing. J. Food Eng., 84(2): 231-242.

Altan A.; McCarthy K.L. and Maskan M. (2008b) Extrusion cooking of barley flour and process parameter optimization by using response surface methodology. J. Science Food and Agriculture, 88(9): 1648-1659.

Andersson Y. and Hedlund B. (1991) Extruded whey flour: correlation between processing and product quality parameters. Food Quality and Preference, 2(3): 201-216.

Andersson Y.; Hedlund B.; Jonsson L. and Svensson S. (1979) Extrusion cooking of a high fiber cereal product with crisp-bread character. Cereal Chem., 58 (5): 370-374.

Anitha L. and Chandralekha K. (2010) Effect of Supplementation of Spirulina on Blood Glucose, Glycosylated Hemoglobin and Lipid Profile of Male Non-Insulin Dependent Diabetics. ASIAN J. EXP. BIOL. SCI., 1 (1):36-46.

AOAC (2000) Official Methods of Analysis, $17^{\text {th }} \mathrm{Ed}$. Association of Official Analytical Chemists, Inc. Washington, USA.

APHA (1992) Compendium of methods for the microbiological examination of foods. Inc. American Public Health Association Washington DC.

Bourne M.C. (2002) Food Texture and Viscosity: Concept and Measurement. Publisher: Elsevier Science and Technology Books, $2^{\text {nd }}$ Edition.

Branger B.; Cadudal J.L.; Delobel M.; Ouoba H.; Yameogo P.; Ouedraogo D.; Guerin D.; Valea A.; Zombre C. and Ancel P. (2003) Spirulina as a food supplement in case of infant malnutrition in Burkina-Faso. Archives de Pédiatrie, 10 ( 5) 424-431.

Brncic, M.; Tripalo, B.; Jezek, D.; Semenski, D.; Drvar, N. and Krainczyk, M. (2006) Effect of twin-screw extrusion parameters on mechanical hardness of direct-expanded extrudates. Sadhana 31, 527-536. 
Carvalho C.W.P.; Takeiti C.Y.; Onwulata C.I. and Pordesimo L.O. (2010) Relative effect of particle size on the physical properties of corn meal extrudates: Effect of particle size on the extrusion of corn meal. J. Food Eng., 98(1): 103 109.

Case S.E.; Hamann D.D. and Schwartz S.J. (1992) Effect of starch gelatinization on physical properties of extruded wheat and corn based products. Cereal Chem. 69, 401-409.

Conrad, S.L. (2004) High-protein, soy-based cookies fortified with spirulina. AU J. Technol. 7(3), $145-150$.

Dillon J.C. (2014) Utilization of spirulina in children, chapter 3 in book "The young child nutrition and malnutrition". Antenna Technologies - Geneva, Switzerland. www.antenna.ch.

Ding Q.; Ainsworth P.; Gregory T. and Hayley M. (2005) The effect of extrusion conditions on the physicochemical properties and sensory characteristics of rice based expanded snacks. J. Food Eng. 66, 283-289.

Ding Q.B.; Ainsworth P.; Plunkett, A.; Tucker G. and Marson H. (2006) The effect of extrusion conditions on the functional and physical properties of wheat-based expanded snacks. J. Food Eng., 73 (2): 142-148.

Dolly W.D. (2014) Biotechnological Potentials and Role of Cyanobacteria in Agriculture and Industry. Division of Microbiology Indian Agricultural Research Institute New Delhi110012, India.

El-Sharkawi A.S.M. (2004) Quailty attributes of extruded high protein blends. Ph.D. Thesis, Fac. Agric., Menofia Univ., Egypt.

FDA Talk Paper (1981) No. 41,160, June 23, 1981, US Food and Drug Administration.

Gujska E. and Khan K. (1990) Effect of temperature on properties of extrudates from high- starch fraction of navy, pinto and garbanzo beans. J. Food Sci., 55(2): 466-469.

Gujska E. and Khan K. (1991) Feed moisture effects on functional properties, trypsin inhibitor and hem agglutinating activities of extruded bean high starch fractions. J. Food Sci., 56 (20) 443 447.

Habib M.A.B.; Parvin M.; Huntington T.C. and Hasan M.R. (2008) A Review on Culture, Production and Use of Spirulina as Food for Humans and Feeds for Domestic Animals and Fish, FAO Fisheries and Aquaculture Circular No. 1034.

Haeng-Shin Lee; Yang-Hee Cho; Seon-Oh Park; Seung-Hee Kye; Bok-Hee Kim; Tae-Shik Hahm; Meehye Kim; Jong Ok Lee and Cho-il Kim (2006) Dietary exposure of the Korean population to arsenic, cadmium, lead and mercury. Journal of Food Composition and Analysis 19, S31-S37.
Hagenimana A.; Ding $X$. and Fang T. (2006) Evaluation of rice flour modified by extrusion cooking. J. Cereal Sci. 43, 38-46.

Harvey T.C. and Catherine G.C. (1982) Aseptically packaged papaya and guava puree: Changes in chemical and sensory quality during processing and storage. J. Food Sci., (47) 11641169.

Hussein E.H. (2000) Chemical and nutritional evaluation of high protein extrudates. Ph.D. Thesis, Fac. Home Economic, Minufiya Univ., Egypt.

Iqbal, A.; Khalil, I.A.; Ateeq, N. and Khan, M.S. (2006) Nutritional quality of important food legumes. Food Chem. 97, 331-335.

Joshi S.M.R.; Bera M.B. and Panesar P.S. (2014) Extrusion cooking of maize/spirulina mixture: factors affecting expanded product characteristics and sensory quality. Journal of Food Processing and Preservation 38(2) 655-664.

Jozinovic, A.; Subaric, D.; Durdica Ackar; Babic, J.; Mirela Planinic; Mariana Pavokovic and Marijana Blazic (2012) Effect of screw configuration, moisture content and particle size of corn grits on properties of extrudates. Croatian J. Food Sci. Technol. 4 (2) 95-101.

Kang D.H.; Rhee M.S. and Costello M. (2003) Development of miniaturized four-culture method for the rapid enumeration of four bacterial groups in ground beef. Letters Appl. Microbiol., 36: 197-202.

Kelly Moorhead; Bob Capelli and Cysewski R. Gerald (2011) Spirulina Nature's Super food. $3^{\text {rd }}$ edition published by Cyanotech Corporation, 734460 Queen Kaahumanu Hwy \#102, KailuaKona, HI 96740, USA.

Korea Food and Drug Administration (2003) Food code. Seoul: KFDA.

Llobet, J.M.; Falco, G.; Casas, C.; Teixido, A. and Domingo, J.L. (2003) Concentrations of Arsenic, Cadmium, Mercury, and Lead in Common Foods and Estimated Daily Intake by Children, Adolescents, Adults, and Seniors of Catalonia, Spain. J. Agric. Food Chem., 51 (3) 838-842.

Maity T.; Shah A.; Raju P. S. and Bawa A. S. (2012) Development of ready-to-fry frozen vegetable snack and its quality evaluation. J. Food Sci. Technol. (January-February) 49(1) 4249.

Mao T.; Van de Water J. and Gershwin M. (2005) Effects of a Spirulina-based dietary supplement on cytokine production from allergic rhinitis patients. Journal of Medicinal Food, 8, 27-30.

Murphy M.G.; Skonberg D.I.; Camire M.E.; Dougherty M.P.; Bayer R.C. and Briggs J.L. (2003) Chemical composition and physical properties of extruded snacks containing crabprocessing by-product. J. Sci. Food and Agric., 83(11): 1163-1167. 
Myklestad O.; Christie E.M.; Coote G.G. and McDonald D.J. (1968) Chemical, physical and organoleptic properties of 12 varieties of rice. Division of food preservation, technical paper, 19:33. Commonwealth Sci. and Industrial Research Organization, Australia.

Narmadha T.; Sivakami V.; Ravikumar M. and Mukeshkumar D. (2012) Effect of Spirulina on lipid profile of hyperlipidemics. World Journal of Science and Technology, 2, 19-22.

Navacchi M.F.P.; Monteiro de Carvalho J. C.; Takeuchi K. P. and Danesi E.D.G. (2012) Development of cassava cake enriched with its own bran and Spirulina platensis. Acta Scientiarum Technology (Maringá), 34 (4) 465472.

Nour El-Deen A. Eman (2013) Studies on some snack market meals. Ph.D. Thesis, Fac. Agric. Moshtohor, Benha Univ., Egypt.

Kabiel M. Eman (2007) Technological and nutritional studies on some snacks. M.Sc. Thesis, Fac. Agric., Menofia Univ., Egypt.

Obatolu V.A.; Skonberg D.I.; Camire M.E. and Dougherty M.P. (2005) Effect of moisture content and screw speed on the physical chemical properties of an extruded crab-based snack. Food Sci. Tech. International., 11(2): 121-127.

Õzer E.A.; Ibanoğlu Ş.; Ainsworth P. and Yağmur C. (2004) Expansion characteristics of a nutritious extruded snack food using response surface methodology. Eur. Food Res. Technol., 218(5): 474-479.

Parry E.I.D. (India) Limited (2014) Spirulina for Children. Parry Nutraceuticals Division. Dare House, $4^{\text {th }}$ Floor, \# 234, N.S.C. Bose Road, Parrys Corner, Chennai - 600001, India. www.parrynutraceuticals.com.

Patel A.; Mishra S. and Glosh P. (2006) Antioxidant potential of C-phycocyanin isolated from cyanobacterial species Lyngbya phormidium and Spirulina sp. Indian Journal of Biochemistry and Biophysics, 43, 25-31.

Ragab H.G. (1992) Production of some snack foods through extrusion processing of some cereal and their by-products. Ph.D. Thesis, Fac. Agric., Al-Azhar Univ., Egypt.

Raja W.H.; Kumar S.; Bhat Z.F. and Kumar P. (2014) Effect of ambient storage on the quality characteristics of aerobically packaged fish curls incorporated with different flours. Springer Plus, 3(1)106-115.

Ramadan M.F.; Asker M.M.S. and Ibrahim Z.K. (2008) Functional bioactive compounds and biological activities of Spirulina platensis lipids. Czech J. Food Sci., 26(3)211-222.

Ramesh S.; Manivasgam M.; Sethupathy S. and Shantha K. (2013) Effect of Spirulina on Anthropometry and Bio-Chemical Parameters in School Children. IOSR Journal of Dental and
Medical Sciences, 7(5) 11-15. (IOSR-JDMS) eISSN: 2279-0853, p-ISSN: 2279-0861.

Ravi R.; Roopa B.S. and Bhattacharya S. (2007) Texture evaluation by uniaxial compression of some snack foods. Journal of Texture Studies 38, 135-152.

Reid, I., Laronne, J.B. and Powell, D.M. (1998) Flash-flood and bedload dynamics of desert gravel-bed streams. J. Food Sci. 58, 9-20.

Robert Henrikson (2010) Spirulina "World Food" How this micro algae can transform your health and our planet. Library of Congress Catalog Card Number: 89-091683, ISBN 1453766987, EIN-13 9781453766989. Published by Ronore Enterprises, Inc., USA.

Robertson, G.L. (1979) The fractional extraction and quantitative determination of pectic substances in grapes and musts. American J. of Enolvogyol. and Viticulture, 30: 182-186.

Semaska C., Kong $X$. and Hua Y. (2010) Optimization of Extrusion on Blend Flour Composed of Corn, Millet and Soybean. Pakistan Journal of Nutrition 9 (3) 291-297.

Seshadri C.V. (1993) Large scale Nutritional supplementation with spirulina alga. All India Coordinated Project on Spirulina. Shri Amma Murugappa Chettiar Research Center (MCRC) Madras, India.

Sharoba A.M. (2004) Effect of heat transfer on the rheological and mechanical properties of some selected foods. Ph.D Thesis, Fac. of Agric., Moshtohor, Zagazig Univ., Egypt.

Sharoba A.M. (2014) Nutritional value of spirulina and its use in the preparation of some complementary baby food formulas. Journal of Food and Dairy Sci., Mansoura Univ., 5 (4) 517 538.

Sharoba, A.M.; Farrag, M.A. and Abd El-Salam, A.M. (2013) Utilization of some fruits and vegetables waste as a source of dietary fiber and its effect on the cake making and its quality attributes. Journal of Agroalimentary Processes and Technologies, 19 (4), 429-444

Skalaki C. and Sistrunk W.A. (1973) Factors influencing color degradation in concorde grape juice. J. Food Sci., 38, 1060-1064.

Snedecor G. W. and Cochran W. G. (1989) Statitical methods. 8th ed. Iowa State Univ. Press, Ames, Iowa.

Spolaore P.; Joannis-Cassan C.; Duran E. and Isambert A. (2006) Commercial applications of microalgae. Journal of Bioscience and Bioengineering, 101, 87-96.

Suknark K.; Phillips R.D. and Huang Y.W. (1999) Tapioca-fish and tapioca-peanut snacks by twinscrew extrusion and deep fat frying. J. Food Sci., 64(2) 303-308.

Tangkanakul, P.; Tungtrakul, P. and Mesomya, w. (1999) Nutrient contents of commercial snack food products. Kasetsart J. Nat. Sci. 33, 270-276. 
Thind B.B. (2000) Determination of low levels of mite and insect contaminants in food and feedstuffs by a modified flotation method. Journal of AOAC International, 83 (1) 113-119.

Vijayarani D.; Ponnalaghu S. and Rajathivya J. (2012) Development of Value Added Extruded Product Using Spirulina. International Journal of Health Sciences and Research 2 (4) 42-47.

Wang N.; Bhirud P.R.; Sosulski F.W. and Tyler R.T. (1999) Pasta-like product from pea flour by twin-screw extrusion. J. Food Sci., 64(4) 671678.

Zazueta-morales, J.J.; Martínez-bustos, F.; Jacobo-valenzuela, N.; Ordorica-falomir, C. and Paredes-lópez, O. (2002) Effects of calcium hydroxide and screw speed on physicochemical characteristics of extruded blue maize. J. Food Sci. 67, 3350-3358.

\title{
إنتاج وتقيبم بعض المنتجات المبثوقة بإستخدام طحلب الأسبيرولينا
}

\author{
أسامة محمود مرسى * ، أشرف مهذى شرويه، أحمد إبراهيم الدسوقى، همام الطوخى بهلول وعصام محمد عبدالمولى

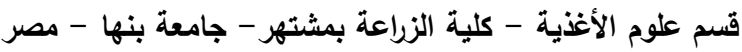 \\ *الأكاديمية العربية للعلوم والتكنولوجيا والنقل البحرى - جامعة الدول العربية
}

\begin{abstract}
تم فى هذه الدراسة إستخدام طحلب الأسبيرولينا وهو أحد الطحالب الخضراء المزرقة الغنى جدا بالبروتين (61.57\%) والمحتوى على كل الأحماض الأمينية المكونة للبروتينات كما أنه يحتوى على نسبة عالية من الأحماض الأمينية الأساسية (38.81\% من نسبة البروتين) ومصدراً

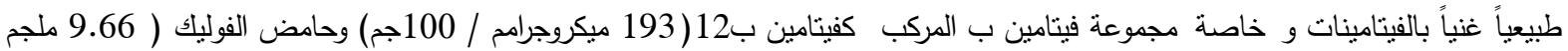
100جم) الذى يساعد على نمو وتغذية دماغ ومخ الطفل والكالسيوم والحديد بنسب ( 1043.63 و 100 (100جم على التوالى)

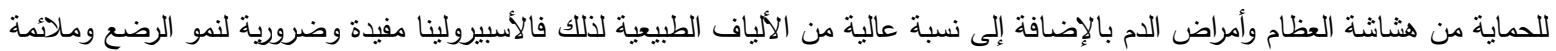
جداً للأطفال وخصوصا فى مرحلة النمو وكبار السن وفاقدى الثهية. كما أنها تساعد كثيراً في حالات الضعف العام وفقر الدم (الأنيميا) والإمساك المزمن. كما أن الأسبيرولينا تحتوى على عنصر السلينيوم (10.0488 ملجم /100جم ) والعديد من الصبغات النباتية مثل الكلوروفيل 1.47\% و و الفيكوسيانين 14.18\% والتى تعتبر من مضادات الأكسدة القوية فهما يمنعان الثيخوخة ويشكلا وقاية دائمة من السرطان. والأسبيرولينا غذاء كامل يضمن توازن وقلوية الجسم. تم إستخدام الأسبيرولينا فى إنتاج الأسناكس بنسب إضافة صفرة ، التقييم الحسى تم أستبعاد نسبة الأضافة 12.5 \% ، وتم تصنيع الأسناكس بالنسب السابقة وتم تحليل الأسناكس المنتج لمعرفة التركيب الكيماوى

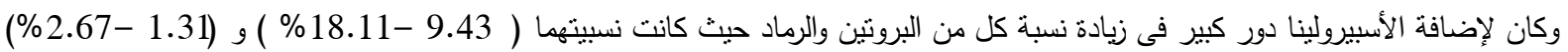
على التوالى وذللك لعينات الكنترول وعينة 10\% أسبيرولينا وتم قياس الخواص الطبيعية مثل الكثافة ومعامل التمدد ومعدل تترب وأمتصاص المبن الماء وإدات نسبة الإضافة إلى تحسن الخواص الطبيعية للأسناكس المضاف إليه الأسبيرولينا. و وتم دراسة الأمان الميكروبيولوجى لعينات الأسناكس الم حضرة بإضافة الأسبيرولينا وكانت جميع العينات أمنة ميكروبيولوجيا. ونم قياس الخواص الريولوجية لعينات الأسناكس بجهاز قياس القوام أنسترون حيث تحسنت وإزدادت ثوابت القوام بإضافة الأسبيرولينا وكانت فى نفس الوقت أقتصادية من حيث التكلفة ولذللك يمكن إنتاجها للإستخدام المحلى وكذا يمكن تصديرها للخارج.
\end{abstract}

